Int. Archs Allergy appl. Immun. 1985;76(suppl. 1):I-III

\title{
Contents, Vol. 76, Supplement 1, 1985
}

\section{Preface}

Baggiolini, M.; Grassi, C 1

Morphology and Respiratory Function of the Alveolar Unit

Burri,P.H 2

The Neutrophil

Baggiolini, M.; Dewald, B 13

Cellular Biology of Pulmonary Macrophages

Furth, R. van 21

A Dramatic Representation of Immunological Cooperative Events

Celada, F.; Lanzavecchia, A 28

Physiology of the IgE System and Mechanisms of Its Dysfunction in Atopic Diseases

Romagnani, S.; Maggi, E.; Del Prete, G.F.; Ricci, M 34

Leukotrienes: Potent Mediators of Airway Constriction

Piper, P.J 43

Cellular Biology and Pathology of Type II Pneumocytes

Chretien, J.; Basset, F.; Jaubert, F.; Soler, P.; Danel, C

Bronchus-Associated Lymphoid Tissue

Bienenstock, J 62

The Role of Basophils and Mast Cells in the Pathogenesis of Pulmonary Diseases

Marone, G 70

'Interstitial Pathology': An Overview of the Chronic Interstitial Lung Disorders

Cantin, A.; Crystal, R.G 83

Pulmonary Sarcoidosis: Pathogenesis, Staging and Therapy

Saltini, C; Crystal, R.G 92

Pulmonary Immunodeficiency

Bellanti, J.A.; Zeligs, B.J.; Sordelli, D.0 101

Problems and Challenges in the Use of Immunomodulating Agents. A General Introduction Spreafico, F 108

Bacterial Products as Immunomodulating Agents

Gialdroni-Grassi, G.; Grassi, C 119

Author Index 128 